\title{
Further Experiments on the Control of Pineapple Gummosis in Puerto Rico ${ }^{1}$
}

\author{
Mario E. Pérez-Escolar ${ }^{2}$
}

\section{INTRODUCTION}

Despite the reduction in acreage, yield, and value of the pineapple crop during the first 5 years of the 1950-60 decade, in relation to the last 5 of the 1940-50 $(1,2)^{3}$, the potentials of this industry are still considered excellent. A new 3-million-dollar cannery is in operation since 1956. The acreage dedicated to pineapple has approached again the high levels of the past. According to estimates gathered from various sources the present area devoted to this crop is in the vicinity of 5,000 acres $^{4}$. This figure represents a marked increase over that in the 1955 census, conducted by Espinet and Olivieri ( 3 ), which showed that only 2,800 acres were planted to pineapples.

Most of the factors limiting fruit production per acre may now be economically controlled, and it is expected that the average yield per acre will soon surpass the present average of only 10.10 tons.

Although the pineapple industry must be economically based on the production of fruit for canning purposes, the exportation of fresh fruit continues to be of great importance, as the price per ton brings the greatest profits to the grower.

Red Spanish continues to be the leading variety grown in the Island. According to Espinet and Olivieri (3), the 1955 census showed that 75 percent of the total acreage was devoted to this variety and the rest to Smooth Cayenne. Because of its medium size, firmness, and shape, the Red Spanish is preferred for exportation as fresh fruit for the New York market. It may also be used for canning, depending on the price and demand of the freshfruit market.

Despite the excellent characteristics of the Red Spanish variety, an insect-provoked condition known as gummosis has been a limiting factor in its economic production. Gummosis, gumming, or gum disease is a condi-

1 Appreciation is expressed to all members of the Entomology staff of the Agricultural Experiment Station. Special mention should be made of the late H. G. Hopwood, of Shell Chemical Co., whose interest and suggestions were so helpful.

${ }^{2}$ Assistant Entomologist, Agricultural Experiment Station, University of Puerto Rico, Río Piedras, P. R.

3 Italic numbers in parentheses refer to Literature Cited, p. 126-7.

4 Guillermo Serra, in charge of the Pineapple Project of the Land Authority of Puerto Rico, provided acreage data for his organization. Enrique Landrón (second largest grower) also provided information. 
tion in which gum exudes from certain places in the rind of the fruit. Holes or cavities develop around the base, open to the outside, and extend from the rind into the flesh of the fruit. Fruits so affected are usually rejected or priced lower when reaching the auction stage at the New lork market. Some growers of this variety claim as high as a 50-percent loss of the fruits exported and there is an unestimated loss in the cannery due to excess slicing to eliminate the dry rot holes.

Field and laboratory experiments showed that the feeding of the larvae of an undescribed species of the genus Batrachedra, Lepidoptera, provoked the exudation of gum (4). Experimentation with chemicals indicated that gumming provoked by this insect can be controlled. Such insecticides as Chlordane, Rhothane, Toxaphene, Parathion, Heptachlor, and Aldrin-Volck oil mixture were effective. A minimum of three spray applications was necessary for control but additional applications improved control. The first spray application was made at any time during blossoming, the others spaced at 2- or 3-week intervals.

A seasonal history study of the causal insect indicated that female $B a$ trachedra sp. moths are attracted to blossoming pineapple fruits. The interrelation of egg deposition and this stage of development of the fruit was established. At the end of 1955 experiments were planned for the 1956 growing season in which only two spray applications of each of the six chemicals found effective were to be made at blossoming time only. A sticker, Shell Tenac, was to be added to half of the treatments to evaluate its effectiveness. If the experiment were successful, a second test was to be conducted the following year to compare one and two applications with the outstanding chemical or chemicals of the group under test. In addition, residue assay was to be taken in consideration, because Puerto Rican pineapples shipped to the United States are subject to the Food and Drug Administration regulations which require a residue clearance on agricultural commodities in interstate commerce.

This paper deals with the description and results of these experiments conducted during the 1956 and 1957 seasons at the farm of Enrique Landron in Vega Baja, and the conclusions obtained from them.

\section{MATERIALS AND METHODS}

1956 EXPERIMENT

The field selected for the 1956 experiment was a first-crop 14-month-old planting of the Red Spanish variety which had been carbided ${ }^{5}$ on November $4,1955$.

5 Carbiding consists of an application of an acetylene solution, produced by treating calcium carbide with water, to the growing point of individual pineapple plants to insure uniform blossoming. 
The experiment consisted of 64 plots involving 16 treatments- 14 chemical treatments and 1 check duplicated for the balance of the design-replicated 4 times in a $4 \times 4$ simple lattice design. Each plot was 35 feet wide and 60 feet long, and consisted of five banks of the double-row system or approximately 400 plants per plot. The description of each treatment is given in table 1.

TABLE 1.-A summary of treatments used and results oblained in the pineapple-gummosis-control experiment at Vega Baja, harvested A pril 15, 1956, on the tolal num-

ber of fruits per plot on the shaded and sunny sides of the bankt

\begin{tabular}{|c|c|c|c|c|}
\hline $\begin{array}{l}\text { Treatment } \\
\text { No. }\end{array}$ & Material2 $^{2}$ & $\begin{array}{l}\text { Concentration per } 100 \\
\text { gal. of water }\end{array}$ & $\begin{array}{c}\text { Mean gum } \\
\text { index }\end{array}$ & $\begin{array}{l}\text { Better at 1- } \\
\text { percent } \\
\text { than treat- } \\
\text { ment No. }\end{array}$ \\
\hline 2 & Chlordane (8 lb./gal. conc.) & 1/2 gal. & 4.22 & 13 \\
\hline 12 & $\begin{array}{l}\text { Endrin (1.6 lb./gal. conc.) }+ \\
\text { Parathion (15-percent W. P.) }\end{array}$ & 1 qt. $+11 / 2$ lb. & 4.26 & 13 \\
\hline 3 & Rhothane (50-percent W. P.) & $4 \mathrm{lb}$. & 5.09 & 13 \\
\hline 5 & Toxaphene (6 lb./gal. conc.) & $1 \mathrm{qt}$. & 6.43 & 13 \\
\hline 10 & Heptachlor (2 lb./gal. conc.) & $1 / 2 \mathrm{gal}$. & 6.48 & 13 \\
\hline 1 & Chlordane (8 lb./gal. conc.) & $1 / 2 \mathrm{gal}$. & 6.53 & 13 \\
\hline 14 & Endrin (1.6 lb./gal. conc.) & $1 \mathrm{qt}$. & 6.91 & 13 \\
\hline 6 & Toxaphene (6 lb./gal. conc.) & $1 \mathrm{qt}$. & 7.20 & 13 \\
\hline 11 & $\begin{array}{c}\text { Endrin (1.6 lb./gal. conc.) }+ \\
\text { Parathion (15-percent W. P.) }\end{array}$ & $1 \mathrm{qt} .+1 / 2 \mathrm{lb}$. & 7.47 & 13 \\
\hline 15 & Endrin (1.6 lb./gal. conc.) & $1 \mathrm{qt}$. & 7.77 & 13 \\
\hline 4 & Rhothane (50-percent W. P.) & $4 \mathrm{lb}$. & 8.33 & 13 \\
\hline 9 & Heptachlor (2 lb./gal. conc.) & 1/2 gal. & 9.34 & 13 \\
\hline 8 & Parathion (15-percent W. P.) & $11 / 2 \mathrm{lb}$. & 11.54 & 13 \\
\hline 7 & do. & $11 / 2 \mathrm{lb}$. & 13.02 & 13 \\
\hline 13 & Untreated check & - & 38.09 & - \\
\hline
\end{tabular}

1 S.E. for means of treatments 1 to $14=3.4124$; S.E. for check mean $(13)=2.4130$; error d. f. $=44$.

2 A sticker (Shell Tenac) was added at the rate of 1 part to 5 parts of the actual insecticide by weight to treatments $2,4,6,8,10,12,14$. W. $P$. = wettable powder.

${ }^{3}$ Applied at the rate of 150 gal., approximately.

The sprays were applied by means of a 15-gallon power sprayer (John Bean, Spartan model) delivering approximately 150 gallons of finished spray per acre. Spray was directed to individual fruits by three rapid movements: to the top of the fruit, around the fruit, and to its base. Spray dates were January 20 and 27, 1956. The first, basal whorl of flowers was open in the first spray.

The experiment was harvested on April 15, 1956. The fruits from each plot were individually examined and classified as to the size. Since personal 
observations confirmed by actual counts indicated differences at blossoming time between fruits from the sunny and shaded sides of the banks, care was taken to obtain separate data on gummosis for both sides. On the average, plants on the sunny side of the bank blossom earlier than those on the shaded side. ${ }^{6}$ Considering the fact that oviposition by the female moth takes place only at blossoming, differences in oviposition abundance could also occur, thus affecting the incidence of gummosis.

Through the courtesy of Shell Co. of Puerto Rico, their Denver laboratories ran the residue analysis for Endrin insecticide.

\section{EXPERIMENT}

The field selected for the 1957 experiment was very close to that selected for the previous year. It was also a 14-month-old first-crop field carbided November 29, 1956.

The experiment consisted of 64 plots involving 16 treatments with only 1 check, replicated four times in a balanced incomplete-block design. Each plot was 35 feet wide and 30 long. Thus, each plot consisted of 5 doublerow banks, or approximately 200 plants. In this experiment the description of all treatments is given in table 2. Two new insecticides, Dieldrin and Malathion, were added to replace the Parathion-Endrin mixture and the extra check.

The same equipment and techniques used in 1956 were followed in this experiment. Spray dates were February 6 and 14, 1957. The first basal whorl of flowers was open at the time of the first spray.

The experiment was harvested on April 29, 1957. Data were also obtained separately in regards to the position of plant in the bank, and the size of fruit was also recorded. Forty fruits per treatment were collected at random for residue analysis.

\section{RESULTS AND DISCUSSION}

Tables 3 to 6 summarize the results obtained in both experiments and their statistical interpretation. The gum index was calculated as the ratio of the number of gum-affected fruits to the total number harvested in each treatment. The comparisons between treatment means were made according to the $Q$ test (Student, Newman, and Keuls).

\section{EXPERIMENT}

Table 1 shows the results of the 1956 experiment and their statistical interpretation based on all fruits of each treatment. All treatments were

"By the "sunny side" of the bank is meant that which is exposed to the sun during the morning hours. In general, it has been observed for the Island of Puerto Rico that there is a greater light intensity during the morning hours. Actinometer data from Gurabo, obtained by M. A. Tió, demonstrate the validity of this statement. 
superior to the untreated check at the 1-percent level of significance. There were no differences among the insecticidal treatments. The addition of a sticker did not improve control. Tables 3 and 4, presenting the analysis based on the position of the fruit in relation to the sun, show similar results.

A $t$-test was performed using only three replicated samples to determine gum-index differences, if any, between fruits from the sunny and shaded

TABLE 2.-A summary of treatments used and results obtained in the pineapple-gummosis-control experiment at Vega Baja, harvested April 29, 1957, on the total number of fruits per plot on the shaded and sunny sides of the bank

\begin{tabular}{|c|c|c|c|c|c|c|}
\hline $\begin{array}{c}\text { Treat- } \\
\text { ment } \\
\text { No. }\end{array}$ & Material & $\begin{array}{c}\text { Concentra- } \\
\text { tion per } \\
100 \text { gal. of } \\
\text { water }{ }^{2}\end{array}$ & $\begin{array}{c}\text { Number } \\
\text { of } \\
\text { applica- } \\
\text { tions }\end{array}$ & $\begin{array}{c}\text { Mean } \\
\text { gum } \\
\text { index }\end{array}$ & $\begin{array}{c}\text { Better at 1- } \\
\text { percent than } \\
\text { treatment } \\
\text { No. }\end{array}$ & $\begin{array}{l}\text { Better at 5- } \\
\text { percent than } \\
\text { treatment } \\
\text { No. }\end{array}$ \\
\hline 2 & Chlordane (8 lb./gal. conc.) & 1/2 gal. & 2 & 3.21 & $\begin{array}{c}16,3,13 \\
15\end{array}$ & $\begin{array}{c}16,3,13 \\
15,11\end{array}$ \\
\hline 6 & Endrin (1.6 lb./gal. conc.) & $1 \mathrm{qt}^{3}$ & 2 & 5.19 & 16,3 & $\begin{array}{c}16,3,13, \\
15\end{array}$ \\
\hline 8 & Toxaphene (6 lb./gal. conc.) & $1 \mathrm{qt}$. & 2 & 6.20 & 16,3 & $\begin{array}{c}16,3,13, \\
15\end{array}$ \\
\hline 4 & Heptachlor (2 lb./gal. conc.) & 1/2 gal. & 2 & 8.77 & 16,3 & 16,3 \\
\hline 7 & Toxaphene (6 lb./gal. conc.) & 1 qt. & 1 & 10.24 & 16,3 & 16,3 \\
\hline 12 & Dieldrin (1.5 lb./gal. conc.) & $1 \mathrm{qt}$. & 2 & 11.61 & 16,3 & 16,3 \\
\hline 1 & Chlordane (8 lb./gal. conc.) & $1 / 2 \mathrm{gal}$. & 1 & 11.65 & 16,3 & 16,3 \\
\hline 5 & Endrin (1.6 lb./gal. conc.) & $1 \mathrm{qt}$. & 1 & 12.89 & 16 & 16,3 \\
\hline 9 & Rhothane (50-percent W. P.) ${ }^{1}$ & $4 \mathrm{lb}$. & 1 & 13.65 & 16 & 16,3 \\
\hline 10 & do. & $4 \mathrm{lb}$. & 2 & 14.37 & 16 & 16,3 \\
\hline 14 & Parathion (15-percent W. P.) & $1 \frac{1}{2} \mathrm{lb}$. & 2 & 16.91 & 16 & 16 \\
\hline 11 & Dieldrin (1.5 lb./gal.) & 1 qt. & 1 & 20.58 & 16 & 16 \\
\hline 15 & Malathion (25-percent W. P.) & $21 / 2 \mathrm{lb}$. & 2 & 22.67 & 16 & 16 \\
\hline 13 & Parathion (15-percent W. P.) & $11 / 2 \mathrm{lb}$. & 1 & 23.26 & 16 & 16 \\
\hline 3 & Heptachlor (2 lb./gal.) & $1 / 2 \mathrm{gal}$. & 1 & 29.85 & 16 & 16 \\
\hline 16 & Untreated check & - & - & 44.98 & & \\
\hline
\end{tabular}

$1 \mathrm{~W} . \mathrm{P} .=$ wettable powder.

${ }^{2}$ Applied at the rate of 150 gal. finished spray per acre.

3 The second application was at the rate of 1 pt. per 100 gal. water.

sides of the bank. A significantly higher gum index (17.68) was obtained with fruits harvested from the sunny side, the gum index on the shady side being 10.20 .

Endrin residues were detected on both peel (0.45 p.p.m.) and pulp (0.26 p.p.m.). Whole-fruit analyses averaged 0.3 p.p.m.

Measurement of the fruits harvested in this experiment revealed that 78 percent of the total were large (12-18) and the remaining 22 percent medium (24 and 30). 
TABLE 3.-A summary of treatments used and results obtained in the pineapple-gummosis-control experiment at Vega Baja, harvested April 15, 1956, on fruits from the shaded side of the bank 1

\begin{tabular}{|c|c|c|c|}
\hline Treatment No. & Material & Mean gum index & $\begin{array}{l}\text { Better at 1-percent } \\
\text { than treatment No. }\end{array}$ \\
\hline $\mathbf{5}$ & Toxaphene & 1.47 & 13 \\
\hline 6 & do. & 3.13 & 13 \\
\hline 2 & Chlordane + sticker & 3.21 & 13 \\
\hline 12 & Endrin + Parathion + sticker & 3.52 & 13 \\
\hline 1 & Chlordane & 3.65 & 13 \\
\hline 3 & Rhothane & 3.93 & 13 \\
\hline 11 & Endrin + Parathion & 4.16 & 13 \\
\hline 14 & Endrin + sticker & 5.20 & 13 \\
\hline 8 & Parathion + sticker & 5.76 & 13 \\
\hline 10 & Heptachlor + sticker & 5.88 & 13 \\
\hline 15 & Endrin & 6.17 & 13 \\
\hline 4 & Rhothane + sticker & 6.36 & 13 \\
\hline 9 & Heptachlor & 8.43 & 13 \\
\hline 7 & Parathion & 12.64 & 13 \\
\hline 13 & Untreated check & 31.12 & 一 \\
\hline
\end{tabular}

1 SE for means of treatment 1 to $14=3.5471$; S.E. for check mean No. $13=$ 2.5082 ; error d. f. $=33$.

2 Materials and concentrations used are the same as those summarized in table 1.

TABLE 4.-A summary of treatments used and results oblained in the pineapple-gummosis-control experiment at Vega Baja, harvested April 15, 1956, on fruits from the sunny side of the bank ${ }^{1}$

\begin{tabular}{r|l|c|c}
\hline Treatment No. & \multicolumn{1}{|c|}{ Materialz } & Mean gum index & $\begin{array}{c}\text { Better at 1-percent } \\
\text { than treatment No. }\end{array}$ \\
\cline { 1 - 2 } 10 & Heptachlor + sticker & 6.83 & 13 \\
2 & Chlordane + sticker & 7.38 & 13 \\
1 & do. & 7.44 & 13 \\
12 & Endrin + Parathion + sticker & 7.45 & 13 \\
9 & Heptachlor & 9.06 & 13 \\
14 & Endrin + sticker & 9.90 & 13 \\
6 & Toxaphene & 9.94 & 13 \\
5 & do. & 10.54 & 13 \\
3 & Rhothane & 11.45 & 13 \\
15 & Endrin & 12.21 & 13 \\
7 & Parathion & 15.37 & 13 \\
11 & Endrin + Parathion & 17.91 & 13 \\
4 & Rhothane + sticker & 22.88 & 13 \\
8 & Parathion + sticker & 49.26 & 13 \\
13 & Untreated check & & - \\
\hline
\end{tabular}

' S.E. for means of treatments 1 to $14=5.5046$; S.E. for check mean No. $13=$ 3.8924 ; Error d. f. $=44$.

2 Materials and concentrations used are the same as those summarized in table 1. 
TABLE 5.-A summary of treatments used and resulls oblained in the pineapple-gummosis-control experiment at Vega Baja, harvested A pril 29, 195\%, on fruits from the sunny side of the bank

\begin{tabular}{r|l|c|c|c|c}
\hline Treatment No. & Materialı & $\begin{array}{c}\text { Number of } \\
\text { applications }\end{array}$ & Mean gum index & $\begin{array}{c}\text { Better at 1-per- } \\
\text { cent than } \\
\text { treatment No. }\end{array}$ & $\begin{array}{c}\text { Better at 5 per- } \\
\text { cent than treat- } \\
\text { ment No. }\end{array}$ \\
\cline { 2 - 4 } 2 & Chlordane & 2 & 5.34 & 16 & $16,13,3$ \\
6 & Endrin & 2 & 7.05 & 16 & $16,13,3$ \\
8 & Toxaphene & 2 & 9.71 & 16 & 16,13 \\
1 & Chlordane & 1 & 11.57 & 16 & 16 \\
7 & Toxaphene & 1 & 14.09 & 16 & 16 \\
12 & Dieldrin & 2 & 14.11 & 16 & 16 \\
4 & Heptachlor & 2 & 15.32 & 16 & 16 \\
10 & Rhothane & 2 & 16.24 & 16 & 16 \\
9 & do. & 1 & 17.79 & 16 & 16 \\
5 & Endrin & 1 & 18.39 & 16 & 16 \\
11 & Dieldrin & 1 & 25.44 & - & 16 \\
14 & Parathion & 2 & 25.77 & - & 16 \\
15 & Malathion & 2 & 28.04 & - & 16 \\
3 & Heptachlor & 1 & 31.90 & - & - \\
13 & Parathion & 1 & 33.31 & - & - \\
16 & Untreated & - & 45.81 & - & - \\
\hline
\end{tabular}

1 Formulations and concentrations are those shown in table 2.

TABLE 6.-A summary of treatments used and results obtained in the pineapplegummosis-control experiment al Vega Baja, harvested A pril 29, 1957, on fruils from the shaded side of the bank

\begin{tabular}{c|l|c|c|c|c}
\hline Treatment No. & Materialt & $\begin{array}{c}\text { Number of } \\
\text { applications }\end{array}$ & Mean gum index & $\begin{array}{c}\text { Better at 1- } \\
\text { percent than } \\
\text { treatment No. }\end{array}$ & $\begin{array}{c}\text { Better at 5-per- } \\
\text { cent than treat- } \\
\text { ment No. }\end{array}$ \\
\cline { 2 - 3 } 2 & Chlordane & 2 & 0.53 & 16,3 & 16,3 \\
6 & Endrin & 2 & 2.07 & 16,3 & 16,3 \\
8 & Toxaphene & 2 & 2.77 & 16,3 & 16,3 \\
4 & Heptachlor & 2 & 3.23 & 16,3 & 16,3 \\
5 & Endrin & 1 & 5.48 & 16,3 & 16,3 \\
7 & Toxaphene & 1 & 5.36 & 16,3 & 16,3 \\
9 & Rhothane & 1 & 6.57 & 16,3 & 16,3 \\
12 & Dieldrin & 2 & 6.98 & 16,3 & 16,3 \\
14 & Parathion & 2 & 8.84 & 16,3 & 16,3 \\
10 & Rhothane & 2 & 10.14 & 16,3 & 16,3 \\
13 & Parathion & 1 & 11.22 & 16 & 16,3 \\
1 & Chlordane & 1 & 13.76 & 16 & 16,3 \\
11 & Dieldrin & 1 & 15.46 & 16 & 16,3 \\
15 & Malathion & 2 & 17.17 & 16 & 16,3 \\
3 & Heptachlor & 1 & 29.15 & 16 & - \\
16 & Untreated & - & 44.56 & - & - \\
\hline
\end{tabular}

1 Formulations and concentrations are those shown in table 2. 


\section{EXPERIMENT}

Statistical analyses for the 1957 experiment was also made both disregarding (table 2) and taking into consideration (tables 5 and 6) the position of the fruit in relation to the sun.

As in the 1956 experiment, the gum index from fruits harvested from the sunny side of the bank, 19.95 , was higher than that from the shaded side, 11.49. This difference was found to be highly significant.

The comparison between the number of applications in general showed that under the conditions of high gum index of the sunny side of the bank the effects of two insecticidal applications proved to be highly significant over one application. No difference was found between one and two applications on the shaded side of the bank where the gum index was lower. When the position of the fruits was disregarded, results of two applications were found to be significant over one (table 4). No significant differences were observed between number of applications from insecticide to insecticide individually.

However, it should be borne in mind that poor uniformity at blossoming time may change this lack of difference between one and two applications, as egg deposition by the female Batrachedra takes place only at this stage of fruit development. Thus, the fruit of a nonblossoming or a slow-blossoming plant may remain unprotected when one spray only is applied, and therefore the fruit-to-be is a potential one for oviposition, and consequently gummosis may develop from the feeding of the unchecked hatching larva. But, despite the difference in gum index between the sides of the bank, the check plots did not show an appreciable difference. This suggests that such climatic factors as light intensity, temperature, winds, and the washing action of rains may possibly have affected fruits located on the sunny side to a greater degree than those on the better protected, shaded side. The interaction of these factors may possibly cause a faster deterioration of the chemicals, thus, a second spray application becomes significant as shown in table 5 .

When the position of the fruit is disregarded for analysis (table 2), or the sunny side only is considered (table 5), the two applications of Chlordane showed the best performance, followed by Endrin and Toxaphene. On the shaded side (table 6) most treatments performed well.

Two applications of either Parathion or Malathion and one application of either Dieldrin, Parathion, or Heptachlor failed to control gummosis significantly over the check in the fruits in the sunny side of the banks. 


\section{RESIDUE DATA}

Table 7 gives a summary of the residue data obtained from the analysis conducted by the various insecticidal companies whose products were under evaluation for gummosis control. ${ }^{7}$

Toxaphene and Heptachlor seem to be the safest insecticides from the standpoint of residues in relation to the known tolerances established for these two chemicals. Either one or two applications may be considered safe.

TABLE 7.-Summary of chemical-residue analysis ${ }^{1}$ for pineapple-gummosis-control experiment al Vega Baja, P.R., April 29, 1957

\begin{tabular}{|c|c|c|c|c|}
\hline Insecticide & $\begin{array}{c}\text { Number of } \\
\text { applications }\end{array}$ & $\begin{array}{l}\text { Average residue } \\
\text { in p.p.m. }\end{array}$ & $\begin{array}{l}\text { Part of fruit } \\
\text { assayed }\end{array}$ & $\begin{array}{l}\text { Accepted tolerance } \\
\text { to date for fruit } \\
\text { or other crops } \\
\text { in p.p.m. }\end{array}$ \\
\hline Endrin & $\begin{array}{l}1 \\
2\end{array}$ & $\begin{array}{l}0.265 \\
.1 \\
.40 \\
.1\end{array}$ & $\begin{array}{l}\text { Peel } \\
\text { Pulp } \\
\text { Peel } \\
\text { Pulp }\end{array}$ & 0 \\
\hline Dieldrin & $\begin{array}{l}1 \\
2\end{array}$ & $\begin{array}{l}.247 \\
.1 \\
.58 \\
.1\end{array}$ & $\begin{array}{l}\text { Peel } \\
\text { Pulp } \\
\text { Peel } \\
\text { Pulp }\end{array}$ & .25 \\
\hline Chlordane & $\begin{array}{l}1 \\
2\end{array}$ & $\begin{array}{l}.145 \\
.43\end{array}$ & $\begin{array}{l}\text { Whole } \\
\text { do. }\end{array}$ & .3 \\
\hline Heptachlor & $\begin{array}{l}1 \\
2\end{array}$ & $\begin{array}{l}.01 \\
.00 \\
.01 \\
.00\end{array}$ & $\begin{array}{l}\text { Peel } \\
\text { Pulp } \\
\text { Peel } \\
\text { Pulp }\end{array}$ & .1 \\
\hline Toxaphene & $\begin{array}{l}1 \\
2\end{array}$ & $\begin{array}{l}1.2 \\
2.0\end{array}$ & $\begin{array}{l}\text { Whole } \\
\text { do. }\end{array}$ & 7.0 \\
\hline Rhothane & $\begin{array}{l}1 \\
2\end{array}$ & & & \\
\hline
\end{tabular}

1 No data were obtained for Parathion, Rhothane and Malathion.

2 Not reported.

One application of Chlordane leaves residues which are below the limits established for this chemical.

Dieldrin leaves residues which are higher than the 0.25-p.p.m. concentration tolerated by the regulations.

Endrin cannot be considered for recommendation despite its effectiveness in the control of gummosis. Residues were detected in both 1956 and

7 The kind cooperation of the following Insecticide Companies is greatly appreciated: 1. Shell Chemical Co., Denver, Col., for Endrin and Dieldrin; 2. Hercules Powder Co., Wilmington, Del., for Toxaphene; 3. Velsical Chemical Corp., Chicago, Ill., for Chlordane and Heptachlor. 
1957 experiments, at least on the peel. As is generally known, no residues are tolerated for this chemical under the regulations of the Food and Drug Administration of the U.S. Department of Health, Education, and Welfare.

\section{CONCLUSIONS}

Chlordane, Endrin, Toxaphene, Rhothane, Heptachlor, and Parathion were consistent in controlling gummosis when applied twice during the blossoming period of the pineapple fruit in both experiments in which they were tested. Two applications of Dieldrin were also effective in the 1957 experiment where it was tested.

Of the outstanding performers only Toxaphene, Chlordane (only one application), and Heptachlor can be recommended from the standpoint of residues.

In general, two spray applications should be made at blossoming time spaced at 7- to 10-day intervals, the first when the first whorl of flowers are open.

\section{SUMMARY}

Gummosis, gumming, or gum disease of pineapples is provoked by the feeding of the larva of an undescribed species of the genus Batrachedra and continues to be a problem of importance in pineapple production with the leading variety of Puerto Rico, the Red Spanish. It is of greatest importance in the fresh-fruit market where. it may cause 50-percent losses. An unestimated loss is also sustained by the canning industry.

Previous work on the biology of the causal insect had demonstrated an interrelation between egg deposition by the female Batrachedra and blossoming of the young pineapple fruit. Two chemical-control experiments conducted during the 1956 and 1957 seasons are presented in detail in this paper. Results demonstrated that gummosis can be effectively reduced by spraying only at blossoming time. Previous experiments reported by the author had shown control, but most of the sprays were applied after blossoming spaced at 2- to 3-week intervals.

In general two spray applications were necessary to effect control, although some of the individual insecticide comparisons between one and two applications showed no significant differences.

A higher gum index was found on fruits harvested from the sunny side than from the shaded side of the bank. Under these high-gum conditions two spray applications were superior to one.

Residue data from whole-fruit analysis, or from peel and pulp analyzed separately, are given. One or two spray applications of Toxaphene or Heptachlor and one of Chlordane left residues which are below the established tolerances. Endrin showed residues above zero. Data from Rhothane were 
not available when this manuscript was written No analysis could be made of Parathion- or Malathion-treated fruits.

\section{RESUMEN}

La gomosis, o la enfermedad de la goma de la piña, producida por la larva de una especie no descrita del género Batrachedra, Lepidoptera, continúa siendo un problema de importancia en el cultivo de la variedad Española Roja, que es la piña que más se siembra en la Isla. Es en el mercado de fruta fresca donde mayores estragos causa esta enfermedad. Se estima que las pérdidas que origina ascienden hasta un 50 por ciento. Hay otras pérdidas cuando se enlata la fruta, que aun no se han podido estimar.

Otros estudios llevados a cabo anteriormente, en cuanto a la biología del insecto que causa la gomosis, señalaron que existe una relación entre la época en que florece la piña y la acción de ovipositar de la hembra de la Batrachedra.

Durante 1956 y 1957 se llevaron a cabo dos experimentos, cuyos datos son los que se presentan en este trabajo.

Los resultados señalan el hecho de que la gomosis puede combatirse eficazmente si las plantas se asperjan sólo durante la florecida. Anteriores experimentos llevados a cabo por el autor demostraron la eficacia de este combate químico, pero en aquellas ocasiones las aspersiones se aplicaron después de la florecida, espaciándolas cada 2 ó 3 semanas.

Generalmente, sólo dos aspersiones del insecticida fueron necesarias para obtener el completo control de la gomosis, sin embargo, cuando se compararon los insecticidas individualmente, el uso de una o de dos aspersiones no demostró diferencia significativa alguna.

El índice de gomosis fué mayor en la fruta cosechada en el lado del banco expuesto al sol que en la del lado sombreado. Cuando hubo índices altos de gomosis en las frutas, el uso de dos aspersiones fué superior al de una sola aspersión.

Se han incluído en este trabajo los datos sobre la cantidad de residuos que dejan los insecticidas usados sobre la fruta completa y sobre la cáscara y la pulpa. La cantidad de residuos que dejan dos aspersiones de toxafeno o heptacloro, o una de clordano, son menores que las toleradas. Las cantidades de residuos que deja el endrín sobrepasan la tolerancia de cero establecida para este insecticida. Aun no hay datos sobre la cantidad de residuos que deja el rotano, ni sobre las de los insecticidas paración y malación.

\section{LITEKATURE CITED}

1. Annual Book of Statistics of Puerto Rico, Economic Development Administration, Office of Economic Research, San Juan, P.R., 491 pp., 1949-50. 
2. Annual Book of Statistics of Puerto Rico, Economic Development Administration, Office of Economic Research, San Juan, P.R., 1957.

3. Espinet, G. R., y Olivieri, J. A., Producción y Mercadeo de la Piña de Puerto Rico, E. \& S. R. 33, Octubre, 1956.

4. Pérez, M. E., Pineapple Gummosis in Puerto Rico and its Control, Tech. Paper 21, Agr. Exp. Sta., Río Piedras, P.R., 71 pp., 14 fig., May 1957. 